\title{
自律神経薬剂に対する生体犬尿道の反応に関する研究
}

\author{
第 1 報 自律神経刺激薬剤の効果について
}

\author{
秋田大学医学部泌尿器科学教室 守年屋至
(主任:土田正義)
}

\section{THE EFFECT OF AUTONOMIC AGONISTS ON THE IN VIVO URETHRA IN THE FEMALE DOG}

\author{
Itaru Moriya \\ Department of Urology, Akita University School of Medicine \\ (Director: Prof. S. Tsuchida)
}

The response of the in vivo urethra to autonomic agonists administered intraarterially was studied by measurements of motility and pressure changes in female dogs. Phenylephrine developed an increase in urethral pressure with shortening of the transverse axis. Isoproterenol produced a decrease in urethral pressure with elongation of the transverse axis. Both acetylcholine and 1, 1-dimethyl-4phenylpiperazinium (DMPP) did not produce consistent pattern in the urethral response. It seems that distribution of adrenergic receptors which respond to adrenergic drugs in the in vivo urethral smooth muscle is predominant in the circular layer and the distribution of cholinergic receptors which respond to cholinergic drugs in the in vivo urethral smooth muscle is uniform in both circular and longitudinal layers.

要旨：雌の雑種成犬を対象として，生体犬の近位尿道に対する自律神経刺激剤の作用を検討した. strain gauge force transducer を尿道外壁に装着し，尿道の動きを縦方向と横方向の成分に分けて把 え，主として縦走筋と輪状筋の動態を観察した。同時に同部位の内圧を micro-tip catheter pressure transducer で測定した。

phenylephrine は尿道内圧の上昇と横方向の短縮反応を, isoproterenol は尿道内圧の減少と横方向の 延長反応を示した。 acetyl choline および DMPPは尿道内圧, 尿道動態のいずれも, 特徵的な反応パター ンを示さなかった。

アドレナリン作動性刺激薬剂は，尿道内圧怙よび尿道動態に一定の反応を示し，とくに $\alpha$ 作用は用量 依存性を示したことから，輪状筋層内には $\alpha$ 受容体の分布が優位であると思われた。一方，コリン作働 性刺激薬剂が尿道内圧および尿道動態に一定の反応を示さなかったことから，コリン受容体が糈走およ び輪状筋に差異なく分布していると思われた。ささらに，特定のパターンを示さなかったのは，コリン受 容体の分布には固体差があるためと考えられた。DMPP は acetylcholine と同様の反応を示し，副交感 神経節の刺激に対する反応と類以していた。

\section{緒 言}

下部尿路機能障害に用いられる各種の自律神経薬剂 の作用機転は, 打もに in vitro 筋条片および in vivo 実 験により検討されている，in vitro筋条片実験は下部 尿路の薬理学的研究に基本的な手法であるが，それか ら得られた成績は in vivo 実験の成績と完全に一致す るとは言えない, in vitro 筋条片実験は, あくまでも in vivo 実験では保たれている立体的な構造を除去した,
平面的な一方向の張力を測定している，その成績は必 ずしも生体の条件と一致しないことを，つねに念頭に おく必要がある。したがって, 生体により近い反応が 得られる点で, in vivo 実験による検討は重要な位置を 占める。しかし，これまでの尿道反応に関する in vivo 実験方法をふりか方ってみると, 以下に列記した 3 点 について検討の余地が残されている.

すなわち第 1 点として, 尿道に連続する膀胱, 尿道 
の後方に存在する直腸などの動態が尿道反応に及ぼす 影響を除去する配慮が十分になされなかったため，尿 道固有の反応を見逃していた可能性があった．第 2 点 として, 通常は内圧測定法のみにより研究が行われて いるために ${ }^{1) 44)}$ ，尿道反応を理解するのに重要な輪状 筋と綐走筋の動的反応を正確に評価することが困難で あった。ささらに第 3 点として, 薬剤投与は括もに静注 法で行われているために年2)4), 薬剂自体の直接的な反 応以外に，血圧変化などの全身状態に続発する反応を 把えていた可能性があった。

私は以上の諸点を考慮して, 実験モデルの作製にあ たり尿道と膀胼を切離し，さらに直腸と子宮・胠の間 を剝離して直腸の動態による影響をも受けないように 細心の注意を払った。 そして, 当教室で製作した尿道 の動的反応を緃・横の二方向に分けて把えることがで ききる strain gauge force transducerを用いで5), 自 律神経刺激薬剤の動脈内投与に対する生体犬尿道の反 応について検討を加えた。 その結果, 薬剤の作用機転 に関して，2，3の興味ある知見を得たので報告する。

\section{実験対象および方法}

対象は体重8 20kg の雑種雌成犬26頭を用いた。麻 酔は thiamylal sodium ( $15 \mathrm{mg} / \mathrm{kg}$ 静注)で導入し， $\alpha$ chloralose (10 20 mg $/ \mathrm{kg} / \mathrm{hr}$ 静注) で維持した。呼吸 は気管切開を执き，pancuronium bromide $(0.08 \mathrm{mg} /$ $\mathrm{kg}$ 静注）で横紋筋を弛緩された状態下にレスピレー ター（Harvard pump Model 607）で管理した.

実験モデルの作製は，既報市と準じて行った。すなわ ち下腹部正中切開扣よび恥骨結合部を切除して, 膀胱 と尿道全長を直視下に露出した。膀胼頸部で尿道を切 断し, 膀胼側切断端は, $3-0$ 綟糸で結紮し, 尿道側 切断端は開放状態とした。両側尿管には，尿管膀胱移 行部より約 $6 \mathrm{~cm}$ 上方の部位で $4 \mathrm{~F}$. カテーテルを插入 し，このカテーテルを介して尿を体外に誘導した。 た，直腸子宮窩より胵と直腸の間を約 $5 \mathrm{~cm}$ にわたり剥 離し, その部位に幅 $3 \mathrm{~cm}$ の板状鈎を挿入して, 直腸の 動さが直接尿道へ影響するのを避けた。ささらに神経反 射による測定系への影響を除外するために，下腹およ び骨盤神経に次の操作を行った。下腹神経は下腸間膜 動脈神経叢より約 $1 \sim 2 \mathrm{~cm}$ 末梢側の部位で, 骨盤神経 は膀胱神経叢より約 $1 \mathrm{~cm}$ 中枢側の部位で切断した。 以 下各測定法の詳細を述べる。

尿道反応測定；尿道には当教室で試作した strain gauge force transducer 尿道外壁に 4-0 絹系を用 いて縫着した. strain gauge force transducerはバネ
板として規格化した大小の台板に燐青銅板を用い，台 板の片側外側面に接着剂で小型䈃 phestel gauge(共和 電業製 KFC-1CL-16L30)を接着した。 大小の台板は直 角に交叉させて 1 対の strain gauge force transducer とし，その変化を電圧の変化として導出した．記録に あたっては尿道の動的反応を粉・横の 2 方向に分け， 延長反応を上方への振れ，短縮反応を下方への振れと なるように，伸縮量の割合を\%で表示した，percentage bending を用いた7). それと同時に尿道反応を 管腔外のみでなく管腔内からも圧の变化として記録す るために, strain gauge force transducer 縫着部位の 尿道に，外尿道口より $4 \mathrm{~F}$. の micro-tip catheter pressure transduser（Miller 社製 Model PC 340）を插入 した.

膀胱内圧測定; 膀胼の反応を内圧の変化として把兄 るために膀脱頂部に小切開を扣き，ここから9F.のシ リコンカテーテルを挿入して固定した，膀脱内に約 $10 \sim 20 \mathrm{ml}$ の生理的食塩水を注入し一定の容量にして statham pressure transducer (Gould 社製 MODEL P50)に連結した。

直腸内圧・血圧測定；直腸には肛門から圧測定用バ ルーンカテーテルを挿入して statham pressure transducer（P50)に連結した。 また，血圧測定用のために 右大腿動脈より $6 \mathrm{~F}$. のカテーテルを挿入し，その先端 が腹部大動脈分岐部より約 $5 \mathrm{~cm}$ 中权側に位置するよ らに固定し，同様に statham pressure transducer （P50）に連結して測定した。そしてこれらの記録には 日本光電製ポリグラフ RM6000を使用した。

使用薬剤和よび投与方法；その内腔容積が1ml とな るように作成した薬剂注入用 $5 \mathrm{~F}$. カテーテルを左大腿 動脈に挿入し，その先端は腹部大動脈分岐部に位置す るように固定した。このカテーテルを介して $1 \mathrm{ml}$ の生 理的食塩水に溶解した薬剤を注入し, 続いてカテーテ ル内に薬剤が残留しないように $2 \mathrm{ml}$ の生理的食塩水を 急速に注入した。 以上の実験方法を図 1 に模式図とし て示した。

使用した自律神経刺激薬剂は $\alpha$ 型刺激薬剤として phenylephrine hydrochloride (興和化学), $\boldsymbol{\beta}$ 型刺激薬 剂として1-isoproterenol hydrochloride (日研化学), コリン作動性薬剤として acetylcholine chloride(第 1 製薬）および神経節刺激薬剤として1，1-dimethyl-4phenylpiperazinium (以下 DMPP と略す) であった.

検討した投与量として phenylephrine は 0.003 , $0.01,0.03,0.1 \mathrm{mg} と し$, isoproterenol は0.0003, 
図 1 実験方法模式図

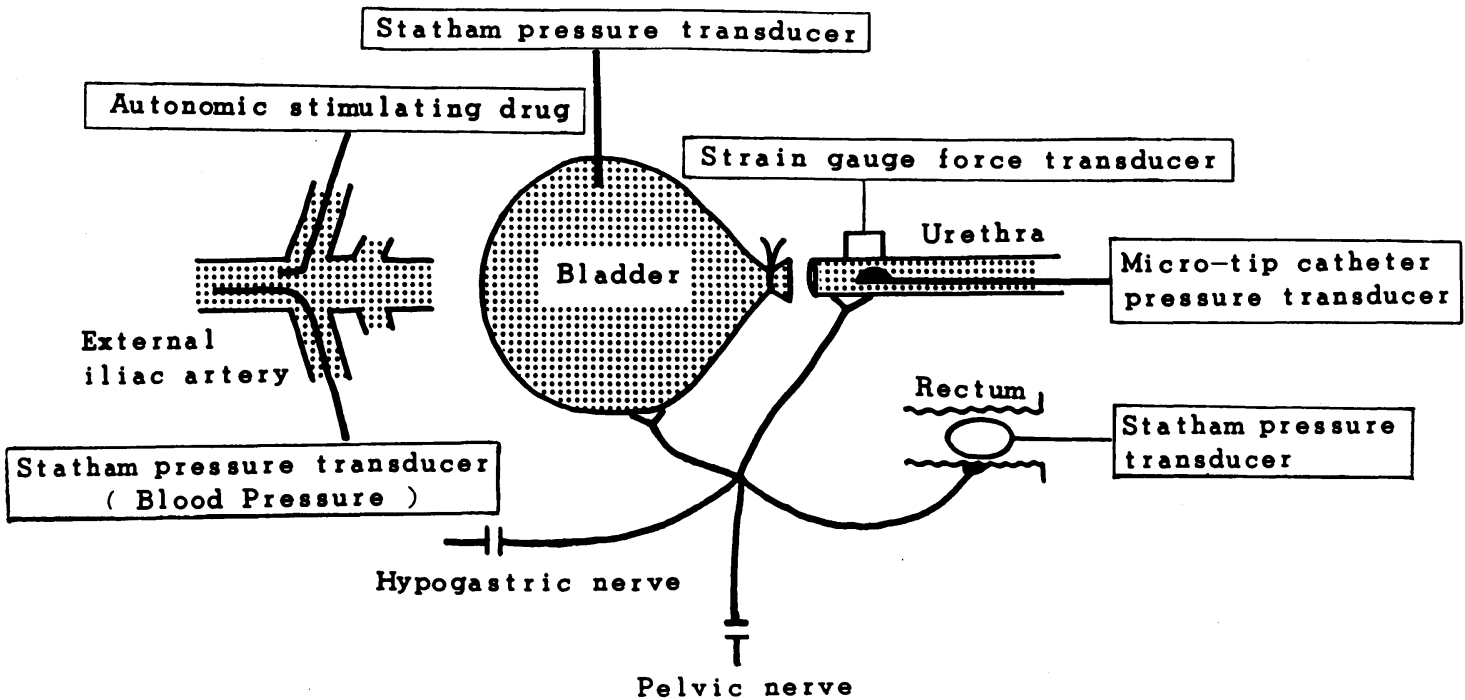

$0.001,0.003,0.01 \mathrm{mg}$ と , acetylcholine は 0.01 , 0.03,0.1, 0.3mg 执よび DMPP は0.003, 0.01，0.03， $0.1 \mathrm{mg}$ のいずれも 4 段階の濃度とした。

\section{実験成績}

1) phenylephrine の効果

8 頭を用いて, 投与量 $0.003,0.01,0.03,0.1 \mathrm{mg}$ と順 次増量して扣の沶のの投与量に対して検討を加えた。 図 2 にDog No. 2における投与量 phenylephrine $0.03 \mathrm{mg}$ の記録例を示した. 血圧は軽度上昇し, 膀胱は 軽度の内圧上昇を示した。尿道は血圧に比較して速や かに反応して，内圧の上昇を示した。尿道の動きにつ いては，横方向は短縮反応を示したが，縦方向は変化 がなかった。 また，直腸は明らかな変化を示さなかっ た.

phenylephrine 投与群における尿道内圧は 8 頭全例 において収縮反応を示し, 用量依存性であった(図 3 )。 尿道の動きは, 横方向はすべて短縮反応であり, 用量 依存性であった(図 4 ). 膀胱内圧は 4 頭で軽度に上昇 した. 值腸内圧も 6 頭で軽度に上昇した. 血圧は $0.1 \mathrm{mg}$ 投与後に上昇した。この血圧反応は尿道反応と比べる と短時間で投与前の状態に戻った。

2) isoproterenol の効果

6 頭を用いて，投与量 $0.0003,0.001,0.003,0.01 \mathrm{mg}$ と順次増量して，おのおのの投与量に対して検討を加 えた。図 5 にDog No. 1に拈ける投与量0.001mg の記 録例を示した．血圧は投与直後に軽度に低下して回復 した. 膀胼内圧は変化なく，尿道内圧は低下を示した。
図 2 Phenylephrine $(0.03 \mathrm{mg})$ 投与例；血圧，膀胱 内圧は変化せず，尿道内圧は上昇を示している，尿 道の動きは横方向で収縮反応を示しているが，縦方 向では変化していない. strain gauge force transducer は上方への振れを延長，下方への振れを短縮 となるように設置されている.

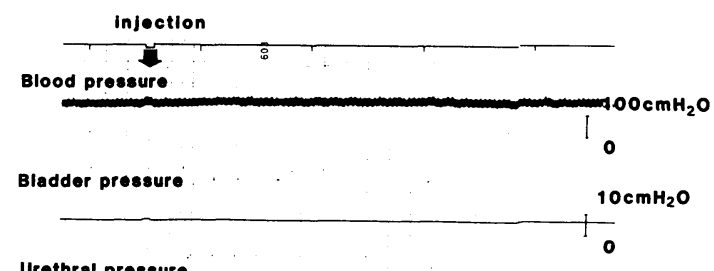

Urethral pressure

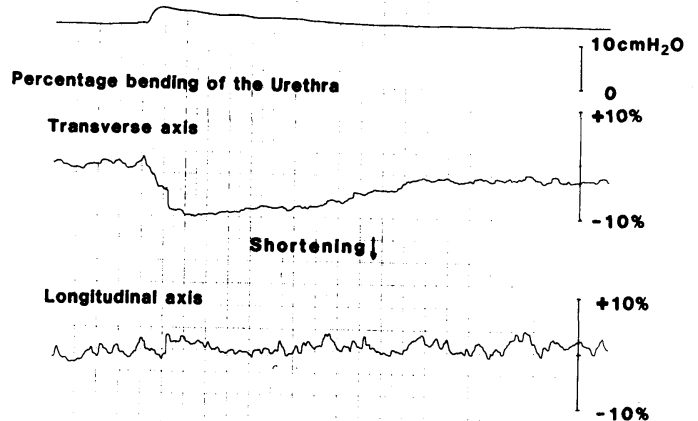

Rectal pressure

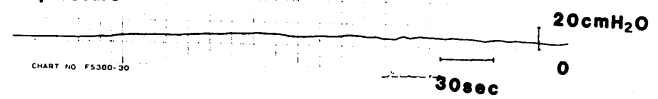

尿道の動きについては，横方向の延長を示したが，縦 方向には変化がなかった. 直腸内圧も変化がなかった. 
図3 Phenylephrineの尿道内圧収縮反応; $0.003 \sim 0.1 \mathrm{mg}$ の投与量でいずれも用量依存性であ る.

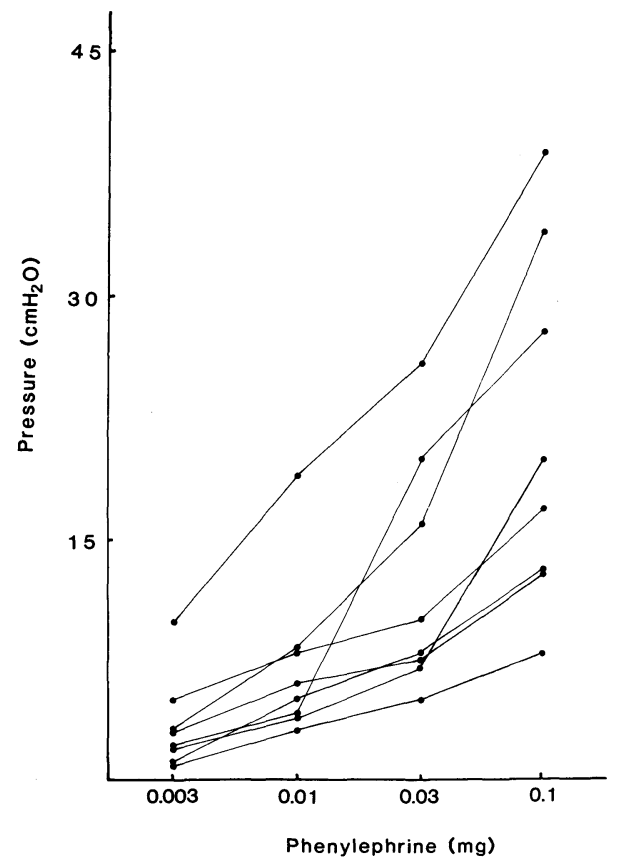

図 4 phenylephrine の尿道横方向短縮反応の動き; Phenylephrine の各投与量で短縮反応はいずれも用 量依存性である。

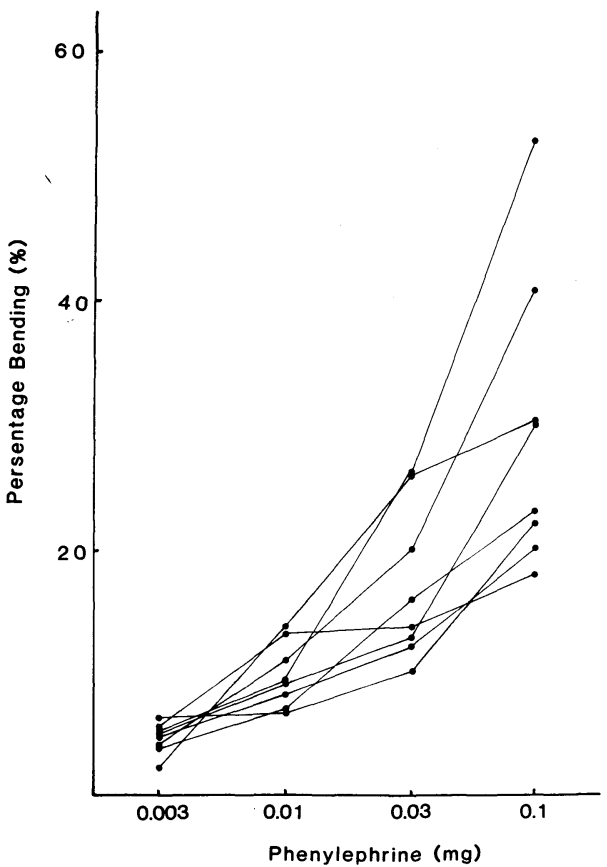

図 5 Isoproterenol (0.001mg) 投与例；尿道内圧は 弛緩反応を示し, 横方向の動きは延長反応を示して いる。
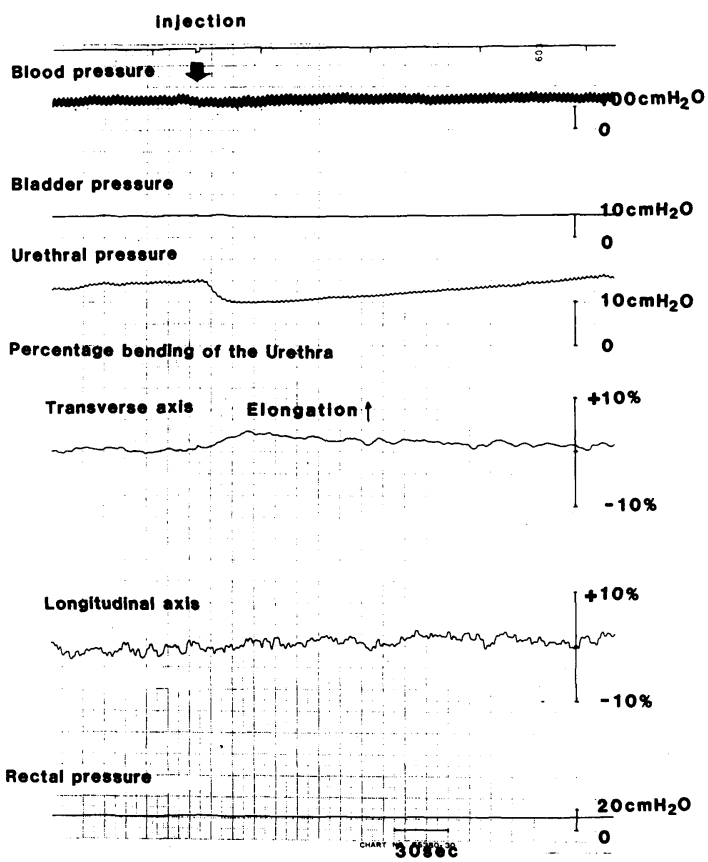

図 6 Isoproterenol の尿道内圧弛緩反応; 0.0003 0.01mgの投与量で用量依存性を示さな w.

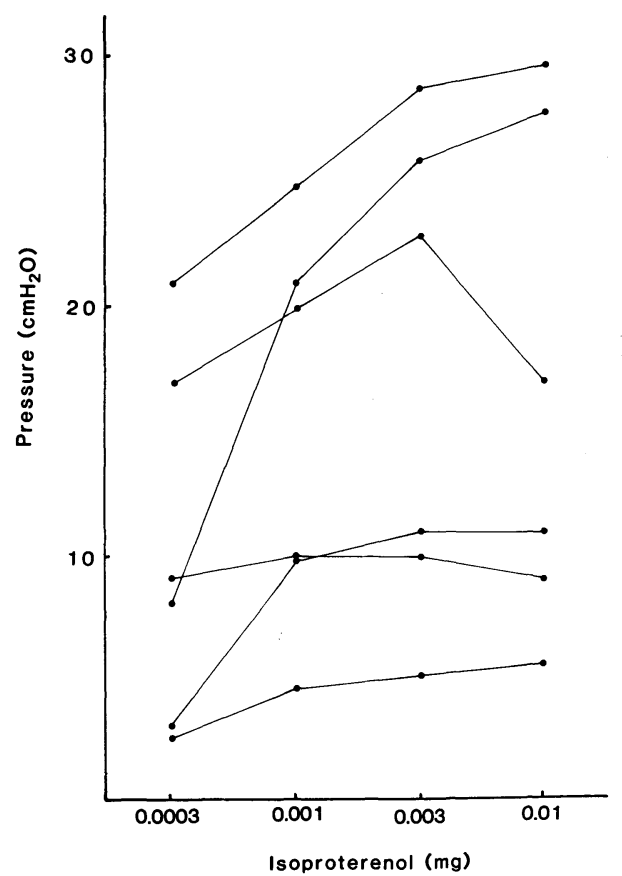


isoproterenol 投与群に抢ける尿道内圧は 6 頭全例 に扣いて弛緩反応を示したが，明らかな用量依存性は 示さなかった(図 6 )，尿道の動きについては，横方向 はすべて延長反応であったが，用量依存性を示さな かった(図 7 )。膀胱内圧は 1 頭に軽度の上昇反応を示 した他は，すべて变化がなかった，直腸内圧は全例に 扣いて変化がなかった. 血圧は低下した後に回復した。 血圧の反応は尿道の反応よりも持続時間が長かった。

3) acetylcholine の効果

11 頭を用いて，投与量 $0.01,0.03,0.1,0.3 \mathrm{mg}$ と順次 増量しておのおのの投与量に対して検討を加えた。眓 8 に Dog No. 9に打ける acetylcholine $0.1 \mathrm{mg}$ の記録 例を示した。血圧は投与後に一時的に低下したのちに 回復した。膀脱内圧は上昇し，尿道内圧は急激な上昇 のあと徐々に低下した。尿道の動きについては，横方 向は一時的に短縮したのちに延長反応を示す二相性の 反応であった，縦方向は強い短縮反応を示した，直腸 内圧は上昇反応を示した。

acetylcholine 投与群に括ける尿道内圧は一定の反 応を示さず個体により一相性, 二相性, 三相性のパター ンを示した，尿道の動きについては，内圧の反応と同 様に，特徵的なパターンを示さなかった．膀脱内圧お

図 7 Isoproterenol の尿道横方向の延長反応；明ら かな用量依存性を示さない。

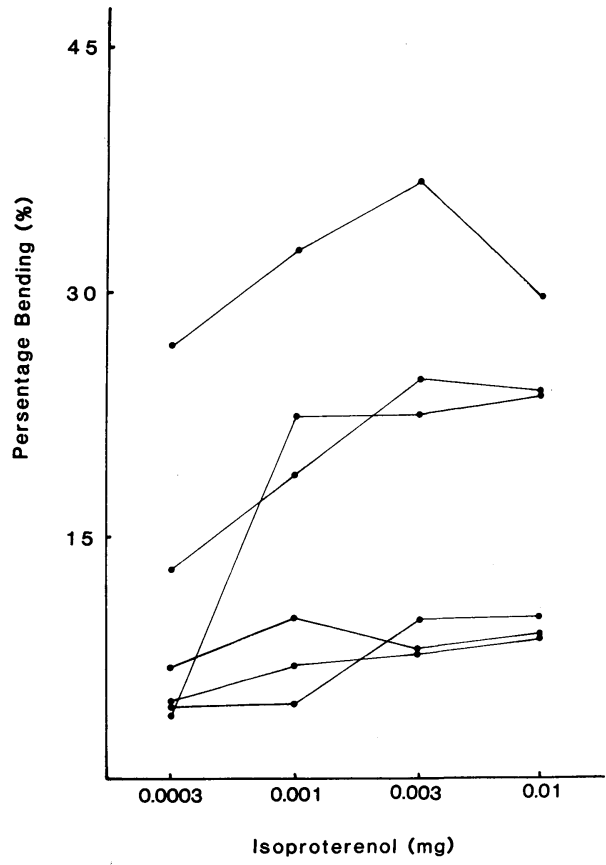

図 8 Acetylcholine $(0.1 \mathrm{mg})$ 投与例；尿道内圧は急 激な上昇のあと徐々に低下している。尿道の動きは 尿道横方向は二相性, 縦方向は一相性の反応を示し ている.
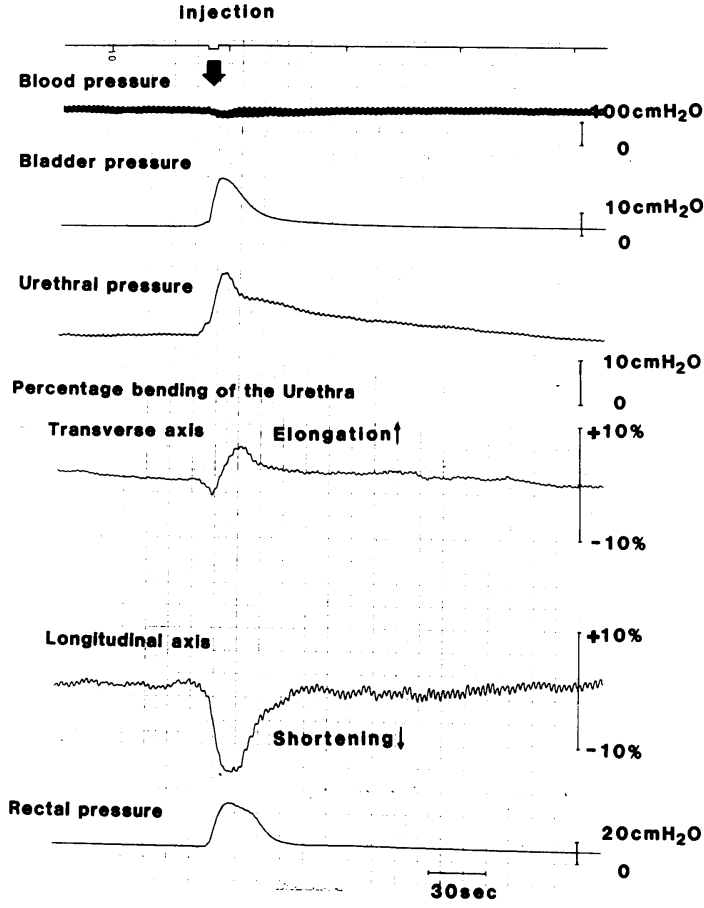

よび直腸内圧は，全例に用量依存性の収縮夫応を示し た．血圧は投与後に低下したのちに回復した。

4) DMPP の効果

9 頭を用いて，投与量 $0.003,0.01,0.03,0.1 \mathrm{mg}$ と順 次増量として，おのおのの投与量に対して検討を加え た. 図 9 にDog No. 4k打ける DMPP投与量0.003 $\mathrm{mg}$ の記録例を示した。血圧は投与後に軽度に上昇し たのちに回復した。膀胱内圧は上昇反応を示し，尿道 内圧は上昇したのちに一時低下し，再びゆるやかに上 昇してもとに戻る三相性のパターンを示した，尿道の 動きについては，横方向ははじめに短縮し，次に延長 し，再び短縮するといら三相性の波形を示したが，縦 方向は，急激な延長反応にひきつづくゆっくりとした 短縮反応を示した。直腸内圧は軽度の上昇反応を示し た。

DMPP 投与群における尿道内圧は個体により一相 性，二相性，三相性の波形を示し，一定の反応を示さ なかった，尿道の動きも内圧反応と同様に，特徵的な パターンを示さなかった。膀胱内圧は全例で用量依存 性の収縮反応を示した，直腸内圧は 6 例で収縮反応を 
図 9 DMPP $(0.03 \mathrm{mg})$ 投与例；尿道内圧はゆっくり とした上昇の後に低下し, 再び上昇するといら三相 性の反応を示している. 尿道の動きは横方向, 縦方 向ともに不規則な反応を示している.

injection
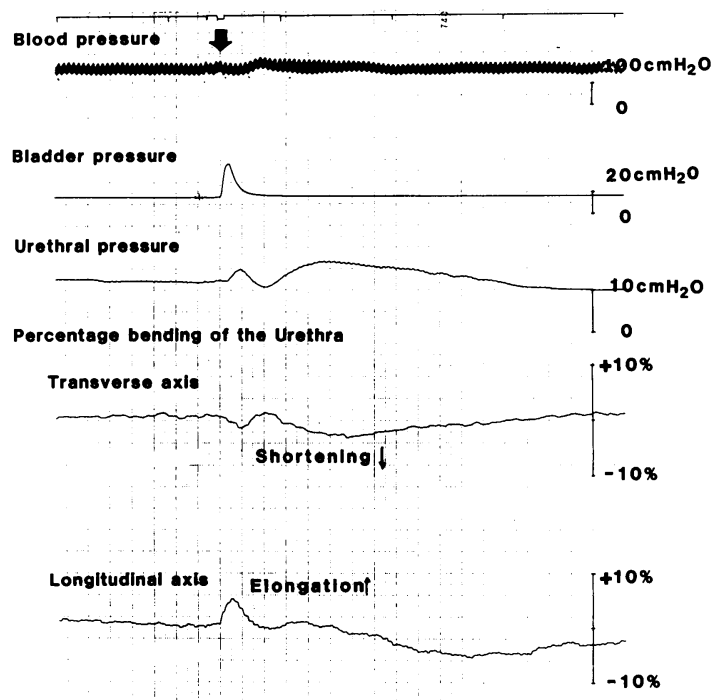

Rectal pressure

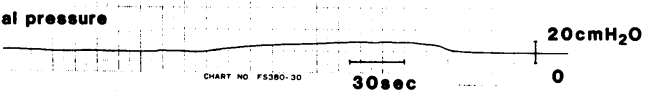

示した. 血圧は投与後に上昇して回復した。

\section{考案}

in vivo 尿道の反応を検討する際の問題点は, 尿道固 有の反応を測定できる実験モデルの設定である，その ためには，尿道周囲の器官として密接な関係をすつ膀 脱の影響を取り除く必要がある，具体的には，解剖学 的連続性を保った状態で膀胼の減圧を目的とするもの と，解剖学的連続性を断ち切るものに大別できる．前 者には膀脱瘻があり ${ }^{8)}$, 後者には膀胱頸部での切

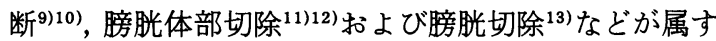
る、本実験では膀胀の内王反応を同時に測定する意図 もあり，膀胱頸部で切断した。この操作で膀胱頸部壁 内を膀胱から尿道に向から血行路に遮断をしたが，動 脈内に投与した薬剂は内腸骨動脈・陰部動脈より尿道 に達し，遠位側から近位側に向から血行路を介して， 反応測定部位の尿道壁に到達した。したがって膀胱頸 部で切断をしても，本研究の目的を損なわないと考壳 る.

次には後方に存在する直腸の影響である，影響を除 外するために直腸切開や直腸摘除などが施行されてい るが13144), 両者とも完全な方法といえない.すなわち,
直腸切開で減圧はできても動きを防げず，直腸摘除は 手技の難さと侵襲の大きさが無視できない.したがっ て, 本実験では直腸子宮窩の䟝離と䟝離部位へ板状鈎 を挿入し，直腸の影響を除外した。その結果，直腸の 反応に伴ら動きが尿道に直接伝わらず，本法は尿道の 周囲器官と独立した尿道固有の反応を把えるモデルと なった。

さて, 薬剤反応の検討には，投与経路も重要である。 一般的に, in vivo 実験では静脈内投与法が多く行われ ているが(1)24), 動脈内投与法は少ない投与量で, 尿道に 対する選択的分布を期待できるという点で優れてい る.しかし，本実験の場合動脈内投与法を採用したた めに, Tanago $5^{15)}$ のアドレナリン作働性薬剂の尿道 反応は，尿道平滑筋から生じたものではなく，血管床 から生じたものであるといら見解を無視できない. 事 実，反応が尿道平滑筋のものか，血管平滑筋のものか は, 本実験成績の解釈に大きな違いを生むことになる。 血圧反応がアドレナリン作働性薬剂の血管床に対する 作用と考劣ても，血圧と尿道には同じ変化が現れるた めに，一見すると，尿道平滑筋と血管床との鑑別は困 難である. しかし，実験成績を検討すると尿道反応と 血圧の変化には時間的なずれがあり, かつ尿道の反応 が比較的長く続いていた。この点に関して, Tulloch ${ }^{16)}$ は尿道内圧の構成因子としては尿道平滑筋より血管床 の役割がはるかに小さいことを報告している。また， Matzumura ら ${ }^{17)}$ は膀胼平滑筋と膀脱血管床のそれぞ れの反応に検討を加え, 両者の反応が独立して生じる ことを報告している。さらに教室の松尾 ${ }^{18)}$ はUPP 法 を用いて尿道平滑筋と尿道血管床の薬理学的効果を検 討し，その主体は尿道平滑筋自体の反応であると述べ ている，以上のことより，得られた反応は主に尿道平 滑筋の反応を把えていると判断した。

尿道平滑筋を縦走筋と輪状筋に分けると，自律神経 薬剂が作用する受容体の分布が両筋層間で必ずしも同 一でないとする報告 ${ }^{19) ~ 22)}$ から, 薬㶡の縦走・輪状筋に 対する反応を別個に把学る手法は有用性が高い。in vitro 筋条片実験は, 両筋層の反応を区分するために縦 方向切片を縱走筋, 横方向切片を輪状筋の反応として 検討されている.一方, in vivo 実験は, 圧側定法のみ が検討手段とすれば，輪状・縦走筋の総合的な反応を 把学られても，両筋層反応の差異を把えられない。し たがって，本研究は尿道内圧を測定すると同時に，そ の圧測定部位の外壁に縫着した大小 2 個の strain gauge force transducer で, 縦・横 2 方向の動きを把 
えたことは，それぞれ樅走筋・輪状筋の反応を推察で きる点で，充分に工夫されている.

尿道反応を動きで把える方法は，私の他には Elhilali ら ${ }^{2324)}$ が行っているにすぎない，しかし，彼らの 方法は，尿道壁の一点と force displacement transducer との間を絹糸で連結する幾分雑な手段であり， 微細な変化を把劣るには適さない。これに対して当教 室で作成した strain gauge force transducer は，既報 のように $1 \mathrm{~mm}$ 程度からの微細な動きも測定可能であ $り^{5)}$, さらに同一部位の縦・横 2 方向の動きを把劣る点 で, 優れている.

従来の薬理学的研究では，ノルアドレナリンが用い られることが多かったが(202022)24) 26), 本研究では $\alpha$ ア ドレナリン作用のみの反応を観察できる phenylephrineを用いた。この場合，本剂の尿道平滑笳の作用 を輪状筋と䊓走筋に区分して検討するために，横方向 筋条片と程方向筋条片で観察した報告では, 縦・横 2 方向のいずれの切片も收縮反応を示すとされている が, 両者の強弱には見解が一致していない(18)27). 横方向 の反応が糈方向の反応よりも優勢とする報告と, 両者 の収縮反応の強さに差異がないとする報告が認められ る ${ }^{1827)}$. しかし, 両者の反応の差異を把える in vivo 実 験の試みはなされず，圧測定法のみで尿道の全体的な 反応として収縮反応を把えることが報告されてい $ろ^{1) \sim 4)}$.

本研究成績からは，縦・横方向の反応をそれぞれ縦 走・輪状筋の反応とみなせば， $\alpha$ アドレナリン作用は 縱走筋には明らかな反応を起こさないが，輪状筋には 用量依存性の収縮反応を起こすと考兄られる。この結 果は $\alpha$ 受容体が尿道平滑筋の中で輪状筋に優位に分 布するという報告 ${ }^{199}$ の正しさを示唆するものであり， in vitro 筋条片実験で横方向切片が程方向切片より優 位な収縮反応を起こすという報告 ${ }^{18)}$ に一致する。

次に $\beta$ アドレナリン作用をるつ isoproterenol を用 いて in vitro 筋条片で検討した報告では, 粉・横方向 のいずれも弛緩反応を示すが，両者の反応の強さには 有意の差がないとする見解と ${ }^{18222}$, 横方向の反応が強 いとする見解27がある。本研究成績では尿道内圧の低 下と, 横方向の延長反応がみられ，抒もに輪状筋が弛 緩反応を示すことが示唆されたが, $0.0003 \sim 0.1 \mathrm{mg}$ の 投与量内では圧低下と横方向の延長反応はいずれも明 瞭な用量依存性を示さなかった。 in vitro筋条片実験 でも， $\beta$ 作用が用量依存性を示さなかったといら報告 があり ${ }^{22)}, \beta$ 受容体の絶対数自体が $\alpha$ 受容体より非常
に少ないことが推察される.

次に, acetylcholine の尿道に対する作用を in vitro 筋条片で検討した報告では，䟞・横 2 方向のいずれも 収縮反応を示しているが，その強弱についての意見は 一致していない。すなわち，縦方向が横方向よりも強 い収縮反応を起こすといら報告と，両者ともに同様の

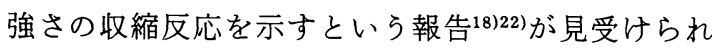
る. 本研究成績では特定の反応を示すアドレナリン作 動性薬剤の場合と異なり，圧反応拈よび動態反応のい ずれも，個体間での変動が大きく，本剂固有の特定パ ターンとして見いだせなかった。たとえば圧反応の場 合には，一，二，三相性の波形が生じたが，常時特定 の波形を示すことはなく, 動態面でも特定の反応を把 えられなかった。この理由の一つとして、コリン受容 体の尿道平滑筋内での分布形式がアドレナリン受容体 と異なることが考えられる。すなわち，アドレナリン 受容体は術前したように輪状筋層内に優位に分布して いるのに対して，コリン受容体は縦走筋·輪状筋間で, その分布に著明な差異がないと思われる ${ }^{28)}$. また, 個体 間でのコリン受容体の分布の差異が尿道反応に個体差 を生ずるとも考えられる。

DMPP については, 膀胱の作用に関する 2,3 の報

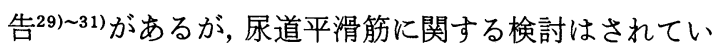
ない.しかし DMPP の作用機転より考学ると, 解剖学 的に下部尿路器官には交感・副交感神経節が多数存在 することから，両神経節の混在した作用が生じるもの と予想された。ところが本研究成績では acetylcholine の反応と同様, DMPP も特定のパターンを示さなかっ たことから，おもに副交感神経節を刺激し，結果的に acetylcholine に類似した反応を示した可能性もある が結論は控えたい。

最後に，これら薬剤が臨床に拈よぼす意義を考えて みたい，本研究成績から， $\alpha$ 扣よび $\beta$ 刺激剤がそれぞ れ横方向の収縮反応, 弛緩反応を示し, とくに $\alpha$ 作用 には用量依存性もあったことより, 輪状筋層には $\alpha$ 受 容体の分布が優位であると考学る。このことは尿失禁 患者に対する $\alpha$ 刺激薬剤の有用性 ${ }^{22) ~ 33) ~}$ り, アドレナリン作働性薬剤の臨床応用は充分期待で きる。一方, acetylchline 拉よび DMPP の成績は， $\alpha$ および $\beta$ 作働性薬剂に認められた特定の尿道反応は 得られず，個体により反応曲線は多様であった。した がって,コリン作動性薬剤を排尿困難例に投与しても, 治療効果として膀胱内圧の上昇と尿道の弛緩が得られ ず，膀胼と尿道の活動はむしろ非協調的になるという 
臨床の場における本剤の問題点を示唆している.

\section{結論}

雑種雌成犬を対象として生体犬尿道に対する自律神 経刺激剤の作用について検討した。薬剤投与を経動脈 的に行い，尿道の反応を，尿道外壁に設置した strain gauge force transducerによる縦・横 2 方向の動きと, 同部位の内腔に挿入した micro-tip カテーテルによる 内圧変化とから検討を加え以下のような結果を得た。

1） phenvlephrine 投与は尿道内圧の上昇と横方向 の短縮反応を示した。

2) isoproterenol 投与は尿道内圧の低下と横方向の 延長反応を示した。

3） acetylcholine 投与は尿道内圧に一定の傾向を示 さず，個体により一相性，二相性，三相性の圧曲線を 示した。 また，尿道の動きは，横方向・縦方向に無变 化，一相性，二相性，三相性の波形を示した。

4）DMPP 投与は尿道内圧打よび動きに一定の傾向 を示さなかった。

$\alpha, \beta$ 刺激薬剤は，尿道内圧，尿道の動きは，一定の 反応としてそれぞれ横方向の収縮と驰緩を示してい た. とくに $\alpha$ 刺激薬剂は用量依存性を示したことから $\alpha$ recepter は招もに輪状筋内に分布していると思わ れた。一方，コリン作動性刺激薬剂は，尿道内圧，尿 道の動きに一定の傾向を示さなかったことから cholinergic receptor は縦走・輪状筋に差異なく分布し ていると思われた。 また，DMPP は acetylcholine と 同様の動きを示し，副交感神経節の刺激で生じた反応 と類似していた。

稿を終えるにあたり, 御指導, 御校閲を賜った恩師土田正 義教授に深く感謝の意を表しますとともに, 種々御教示, 御 助言を頂いた西沢理講師に感謝致します。

な抒, 本論文の要旨は第 24 回日本平滑筋学会総会, 第19回 国際泌尿器科学会 (サンフランシスコ) に扔いて発表した。

\section{文献}

1) Tanago, E.A. and Meyers, F., H.: The "internal sphincter" is it under sympathetic control? Invest. urol., 7, 79-89, 1969.

2) Bruschini, H., Schmidt, R.A. and Tanago, E.A. : The male genitourinary sphincter mechanism in the dog. Invest. Urol., 15, 284-287, 1978.

3) Khanna, O.P., Heber, D. and Gonik, P.: Cholinergic and adrenergic neuroreceptors in urinary tract of female dogs. Urology, 5, 616-624, 1975.

4) Kleeman, F.J.: The physiology of the internal urinary sphincter. J. Urol., 104, 549-554, 1970.
5) Tsuchida, S., Nishizawa, O., Koinuma, N., Harada, T., Moriya, I., Satoh, S., Ebina, K. and Noto, H.: Parired extraluminal strain gauge force transducer. Tohoku J. Exp. Med., 141, 117-118, 1983.

6) Moriya, I., Nishizawa, O., Fukuda, T., Harada, T. and Tsuchida, S. : Effext of dobutamine on the in vivo urethra in the female dog. Accepted for publication in tne Tohoku. J. Exp, Med., 147, 311-314, 1985.

7) Reinke, D.A., Rosenbaum, A.H. and Bennett, D. R. : Patterns of dog gastrointestinal contractile activity monitored in vivo with extraluminal force transducers. Am. J. Digest. Dis., 12, 113-141, 1967.

8) McGuire, E.J.: Experimental observations on the intergration of bladder and urethral function. Invest. Urol., 15, 303-307, 1978.

9) Khalaf, M., Ghoneim, M.A. and Elhilali, M.M. : The effect of exogenous prostaglandins FA $\alpha$ and $\mathrm{E} 2$ and indomethacin on micturition. Brit. J. Urol., 53, 21-28, 1981.

10) Norlén, L. : Effects on the urinary bladder and urethra of different pharmacological treatments. Scan. J. Urol. Nephrol., 11, 7-16, 1977.

11) Johas, U. the Tanago, E.A.: Studies on vesicourethral reflexes. 1. Urethral sphincteric responses to detrusor stretch. Invest. Urol., 12, 357-373, 1975.

12）西沢 理：近位尿道の交感神経系支配に関する研 究. 日泌尿会誌, 72, 32-41，1981.

13）濃沼信夫：神経刺激に対する尿道反応の研究。 Strain gauge transducerを用いての測定を中心 にさて。 日泌尿会誌，73，1296-1311，1982.

14) Girado, J.M. and Campbell, J.B. : The innervation of the urethra of the female cat. Ex. Urol., 1, 44-46, 1954.

15) Tanago, E.A., Mayers, F.H. and Smith, D.R.: Urethral resistance: Igs components and implications. 1. Smooth muscle component Invest. Urol., 7, 136-149, 1969.

16) Tulloch, A.G.S.: The vasculer contribution to intraurethral pressure. Brit.J. Urol., 46, 659 $-664,1974$.

17) Matsumura, S., Taira, N. and Hashimoto, K.: The pharmacological ehavior of the urinary bladder and its vasculature of the dog. Tohoku. J. Exp. Med., 96, 247-258, 1968.

18）松尾重樹：犬近位部尿道こ自律神経支配に関する 研究一in vitro および in vivo 実験による薬理学 的比較検討一. 日泌尿会誌, 74, 1556-1574, 1983.

19) Nergårdh, A. and Boréus, L.O.: The fun- 
ctional role of cholinergic recepters in th outlet region of the urinary bladder: An in vitro study in the cat. Acta Pharmacol. et Toxicol., 32, 467-480, 1973.

20) Khanna, O.P., Barbieri, E.J., Altamura, M. and McMichael, R.: Vesicourethral smooth muscle: Function and relation to structure. Urology, 18, 211-218, 1981.

21) Ek, A., Alm, P., Andersson, K.-E. and Persson, C.G.A.: Adrenoceptor and cholincoeptor mediated responses of isolated human urethra. Scand. J. Urol. Nephrol., 11, 97-102, 1977.

22）村山和夫：尿道の自律神経支配に関する著理学的 研究. 日泌尿会誌，71，33-50，1980。

23) Abdel-Rahman, M., Galeano, C., Lamarche, J. and Elhilali, M.M.: A new approach of the study of the voiding cycle in the cat. Invest. Urol., 18, 475-478, 1981.

24) Hassouna, M., Galeana, C., Abdel-Rahman, M. and Elhilali, M.: Vesicourethral motility following acute spinal cord transectoin in the cat. J. Urol., 131, 370-373, 1984.

25) Khanna, O.P., Barbieri, E.J. and McMchael, McMichael, R.F.: The effect of adrenergic agonistst on vesicourethral smooth muscle of rabbits. J. Pharmacol. Exp. Therap., 216, 95 $-100,1981$.

26) Persson, C.G.A. and Andersson, K.-E. : Adrenocepter and cholincocepter mediated effects in the isolated urethra of cat and guineapig. Clin. Exp. Pharmacol. Physiol., 3, 415-426, 1976.
27) Hassouna, M., Abdel-Hakim, A., Abdel-Rahman, M., Galeano, C. and Elhilali, M.M. : Response of the urethral smooth muscles to pharmacological agents. 1. Cholinergic and adrenergic agonists and antagonists. J. Urol., 129, 1262-1264, 1983.

28) Taira, N., Matsumura, S. and Hashimoto, K. : Effect of tetrodotoxin on the bladder response to pelvic nerve stimulation and intra-arterial 1 , 1-dimethyl-4-phenylpiperazinium and acetylcholine in the dog. Tohoku J. Exp. Med., 97, 283-288, 1969.

29) Kuwahara, M.: DMPP-induced relaxation of the guinea pig urinary bladder. Tohoku. J. Exp. Med., 132, 313-321, 1980.

30) Ozaki, Y. and Harada, M.: Site of ganglion blocking action of gardeneramine and hirsutine in the dog urinary bladder in situ preparation. Japan J. Pharmacol., 33, 463-471, 1983.

31) Diokno, A.C. and Taub, M.: Ephedrine in treatment of urinary incontinence. Urology, 5, 624-625, 1975.

32) Awad, S.A., Downie, J.W. and Kiruluta, H.G. : Alpha-adrenergic agents in urinary disorders of the proximal urethra. Part 1. Sphincteric inciontinence. Brit. J. Urol., 50, 332-335, 1978.

33) Stewart, B.H., Banowsky, L.H.W. and Montague, D.K. : Stress inciontinence: Conservative therapy with sympathomimetic drugs. J. Urol., 115, 558-559, 1976.

（1985年 3 月 23 日受付） 